\title{
Benefits of D-005, a lipid extract from Acrocomia crispa fruits, in the prevention of acute kidney injury induced by nephrotoxicity in rats
}

Benefícios do D-005, um extrato lipídico de frutos da Acrocomia crispa, na prevenção de lesão renal aguda induzida por nefrotoxicidade em ratos

\section{Authors}

Sandra Rodríguez-Salgueiro ${ }^{1,2}$ Leyanis Ocaña-Nápoles Ambar Oyarzábal-Yera ${ }^{1}$ Lucía González-Núñez ${ }^{2}$ Giselle Breña-Betancourt ${ }^{1}$ María Flavia Pérez-Pino ${ }^{1}$ José A. Medina-Pírez ${ }^{1}$ Sonia Jiménez-Despaigne ${ }^{1}$ Vivian Molina-Cuevas ${ }^{1}$

${ }^{1}$ Centro Nacional de Investigación Científica, Departamento de Farmacología, Havana, Cuba. 2Facultad Latinoamericana de Medicina, Departamento de Ciencias Morfológicas, Havana, Cuba.

Submitted on: 03/01/2021. Approved on: 05/12/2021.

Correspondence to: Sandra Rodríguez-Salgueiro. E-mail: sandra.rodriguez@cnic.cu DOI: https://doi.org/10.1590/21758239-JBN-2021-0048

\section{Abstract}

Introduction: Aminoglycoside-induced acute kidney injury (AKI) is a pathology closely linked to oxidative and inflammatory reactions. Taking into account the previous reported antioxidant and anti-inflammatory effects of D-005, a lipid extract obtained from Cuban palm Acrocomia crispa (Arecaceae) fruits, this work aimed to evaluate the effects of D-005 on kanamycininduced AKI. Methods: Male Wistar rats were divided into 7 groups: negative control (vehicle, Tween 65/H2O) and six groups treated with kanamycin to induce AKI: positive control (vehicle), D-005 (25, 100, 200 , and $400 \mathrm{mg} / \mathrm{kg}$ ) and grape seed extract (GSE, $200 \mathrm{mg} / \mathrm{kg}$ ). D-005, vehicle, and GSE oral treatments were administered once daily for seven days, $1 \mathrm{~h}$ before kanamycin $(500 \mathrm{mg} / \mathrm{kg}$, i.p.). Serum uric acid and urea concentrations, renal histopathology, and oxidative markers (malondialdehyde (MDA), sulfhydryl (SH) groups, and catalase (CAT) activity) were assessed. Results: D-005 significantly reduced uric acid and urea levels, starting from D-005 $100 \mathrm{mg} /$ kg. Histopathologically, D-005, at all the tested doses, protected renal parenchyma structures (glomeruli, proximal tubules, and interstitium). These findings were accompanied by a significant reduction of MDA and SH group concentrations as well as restoration of CAT activity. The highest percentages of inhibition were obtained with the dose of $400 \mathrm{mg} / \mathrm{kg}$. GSE, the reference substance, also prevented kanamycininduced biochemical and histopathological changes, as well as reduced MDA and $\mathrm{SH}$ groups and restored CAT activity. Conclusion: The administration of repeated oral doses of D-005 significantly protected against kanamycin-induced AKI, which could be associated with the antioxidant and anti-inflammatory effects of this extract.

Keywords: Acrocomia crispa; Renal Toxicity; Aminoglycoside Antibiotics; Oxidative Stress; Inflammation.

\section{Resumo}

Introdução: Lesão renal aguda induzida por aminoglicosídeos é uma patologia intimamente ligada a reações oxidativas e inflamatórias. Considerando efeitos antioxidantes e anti-inflamatórios relatados anteriormente do D-005, um extrato lipídico de frutos da palmeira cubana Acrocomia crispa (Arecaceae), este trabalho avaliou efeitos do D-005 na LRA induzida por canamicina. Métodos: Dividiu-se ratos Wistar machos em 7 grupos: controle negativo (veículo, Tween $65 / \mathrm{H} 2 \mathrm{O}$ ) e seis grupos tratados com canamicina para induzir LRA: controle positivo (veículo), D-005 $(25,100,200,400 \mathrm{mg} / \mathrm{kg})$ e extrato de semente de uva (ESU, $200 \mathrm{mg} / \mathrm{kg}$ ). D-005, veículo, e tratamentos orais com ESU foram administrados uma vez por dia durante sete dias, $1 \mathrm{~h}$ antes da canamicina $(500 \mathrm{mg} / \mathrm{kg}$, i.p.). Avaliou-se concentrações séricas de ácido úrico e ureia, histopatologia renal e marcadores oxidativos (malondialdeído (MDA), grupos sulfidrila ( $\mathrm{SH}$ ), atividade de catalase (CAT)). Resultados: D-005 reduziu significativamente níveis de ácido úrico e ureia, partindo de D-005 $100 \mathrm{mg} /$ $\mathrm{kg}$. Histopatologicamente, D-005, em todas as doses testadas, protegeu estruturas do parênquima renal (glomérulos, túbulos proximais e interstício). Estes achados foram acompanhados por uma redução significativa das concentrações de MDA e grupo $\mathrm{SH}$, e pela restauração da atividade CAT. As maiores porcentagens de inibição foram obtidas com a dose de $400 \mathrm{mg} / \mathrm{kg}$. ESU, a substância de referência, também evitou alterações bioquímicas e histopatológicas induzidas por canamicina, reduziu MDA e grupos SH e restaurou atividade CAT. Conclusão: A administração de doses orais repetidas de D-005 protegeu significativamente contra LRA induzida por canamicina, que pode estar associada aos efeitos antioxidantes e anti-inflamatórios deste extrato.

Descritores: Acrocomia crispa; Toxicidade Renal; Antibióticos Aminoglicosídeos; Estresse oxidativo; Inflamação. 


\section{INTRODUCTION}

Acute kidney injury (AKI) is a clinical syndrome of varied etiology characterized by a sudden decrease in kidney function, accumulation of waste metabolites, water-mineral imbalance, and systemic symptoms. It is a common problem in intensive care medicine since a moderate AKI increases the risk of death by approximately five times ${ }^{1,2}$.

Several drugs usually used in the clinical setting, including aminoglycoside antibiotics (AMGs), contribute to AKI due to their nephrotoxic side effects. AKI induced by AMG treatment has a worldwide incidence of 5 to $15 \%$, appearing 7 to 10 days after starting the administration of the AMG. The immediate clinical manifestations are: oliguria with dysfunction of renal excretion and increased serum creatinine, urea, and other metabolic products ${ }^{3}$.

The accumulation of AMG in the tubular epithelium triggers the initial phase of AKI leading to a complex interrelation of vascular and tubular processes causing kidney dysfunction. Tubular toxicity by AMG is mainly characterized by several pathological changes in tubular epithelial cells in the proximal segment, associated with an important inflammatory component followed by non-lethal functional alterations of key components involved in the transport of water and solutes ${ }^{4,5}$.

As a consequence of AMG-induced tubular cell damage, some epithelial cells detach leading to formation of casts, composed of cells and proteins, into tubular lumens. The casts obstruct tubular lumens, causing an increase in intratubular pressure, which reduces the excretory function of affected nephrons and elevates the hydrostatic pressure in the Bowman's capsule, thus decreasing glomerular filtration rate. Furthermore, higher intratubular pressure promotes the leakage of filtrate into the interstitial space and peritubular capillaries and lowers the excretion of the filtered products ${ }^{4}$.

Renal vasculature and glomerular filtration function are also affected by AMGs through stimulation of mesangial cell contraction, proliferation, and apoptosis. These processes are mediated by the elevation of cytosolic calcium, oxidative stress, inflammation, and vasoconstrictor release. Moreover, reduced blood flow and glomerular filtration rate may contribute to aggravate AMG-induced tubular damage by probably limiting the availability of oxygen and nutrients, and at the same time, facilitating oxidative stress, similar to ischemic $\mathrm{AKI}^{4}$.
AMG-induced AKI is fatal in some cases. However, patients can survive due to the regenerative capability of tubular cells, which allows them to recover as soon as AMG treatment is stopped ${ }^{6}$. However, even though AKI may be reversible, some patients do not completely recover and usually develop a chronic kidney disease ${ }^{7}$.

$\mathrm{Up}$ to now, there is no effective therapeutic alternative to prevent AMG renal toxicity in clinical practice and current treatments are not able to prevent the progression of AKI towards chronic kidney disease. In this context, it is necessary to search for new alternatives contributing to accelerate the regeneration of renal tubular cells and prevent AKI.

Diverse natural and synthetic substances have displayed beneficial actions on AKI induced by AMGs. Antioxidant agents are among the best candidates due to their efficacy in preventing the generation of reactive oxygen species ${ }^{8-10}$. According to this approach, extracts obtained from plants belonging to Arecaceae family, such as Cocos nucifera and Phoenix dactylifera, have prevented gentamicin-induced AKI in rats ${ }^{11,12}$.

D-005, a saponified lipid extract obtained from the fruit of Acrocomia crispa, endemic palm of Cuba of the Arecaceae family, contains a reproducible mixture of fatty acids, mainly oleic, palmitic, lauric, and myristic while palmitoleic, caprylic, capric, and stearic acids are found in lower concentrations ${ }^{13,14}$.

Recently, D-005 has shown to prevent pathological changes induced by kidney ischemia/reperfusion in rats, by diminishing serum concentrations of creatinine, uric acid, and urea and lessening tubular histopathological changes in kidney cortex. This was linked to D-005 antioxidant effects, since it decreased the concentrations of malondialdehyde (MDA) and sulfhydryl $(\mathrm{SH})$ groups in plasma and kidney homogenate, as well as it has restored catalase (CAT) enzymatic activity in the kidney ${ }^{15}$.

In addition, previous studies revealed that D-005 exerts anti-inflammatory effects in vitro and in vivo by inhibiting the enzymes 5 -lipooxygenase (5-LOX) and cyclooxygenase type 2 (COX-2) and preventing inflammatory infiltration during acute lung damage in mice ${ }^{16,17}$.

Taking into account the crucial role played by oxidative stress and inflammation in the pathophysiology of AMG-induced AKI, as well as the previous antioxidant and anti-inflammatory effects of D-005, this work aimed to evaluate the effects of D-005 on kanamycin-induced AKI. 


\section{Materials and Methods}

\section{Preparation of extracts}

D-005 was obtained from previously authenticated Acrocomia crispa ripe fruits (No. 1982-1031, National Botanical Garden, Havana, Cuba) at Laboratory of Pharmaceutical Chemistry, Natural Products Center (CPN) belonging to the National Center for Scientific Research (CNIC), Havana, Cuba. In brief, the fruits were air-dried, milled at $2.36 \mathrm{~mm}$, and extracted with n-hexane at room temperature. Then, solvent was removed at $60{ }^{\circ} \mathrm{C}$ under vacuum, in a rotary evaporator, and the resulting oil was saponified at reflux with a hydro alcoholic potassium hydroxide solution $(0.5$ $\mathrm{mol} / \mathrm{L})$. Next, the fatty acids were released with $\mathrm{HCl}(10$ $\%$ ) until $\mathrm{pH} 1-2$, and the organic phase was washed with water and dried under vacuum at $110^{\circ} \mathrm{C}^{13,14}$.

D-005 batch thus obtained (Batch S-291215) was characterized by gas chromatography, being its fatty acid composition: lauric $(41.77 \%)$, oleic $(28.10$ $\%)$, myristic $(12.57 \%)$, palmitic $(7.83 \%)$, stearic (2.93\%), capric $(3.33 \%)$, caprylic $(1.73 \%)$, and palmitoleic $(0.05 \%)$ acids, for a total content of fatty acids of $98.30 \%$. D-005 was suspended in Tween 65/ $\mathrm{H}_{2} \mathrm{O}(2 \%)$ just before using.

Grape seed extract (GSE) was used as a reference substance (95 \% proanthocyanidin), Batch: R3992407, from Blackmores (Sydney, Australia). GSE was dissolved in acacia gum $/ \mathrm{H}_{2} \mathrm{O}(1 \%)$ prior to rat administration.

\section{ANIMALS AND EXPERIMENTAL PROTOCOL}

Male Wistar rats (250-300 g) from the National Center for the Production of Laboratory Animals (CENPALAB, Havana, Cuba) were used. Rats were acclimated for 7 days to controlled laboratory conditions $\left(25 \pm 2{ }^{\circ} \mathrm{C}\right.$ temperature, $60 \pm 5 \%$ relative humidity, and 12 hours light/dark cycle) and free access to food and water (standard feed for rodents from CENPALAB). After this period, they were classified as suitable for experimental use. The handling of the animals was carried out according to the Cuban Guidelines for Animal Handling and the Cuban Code of Good Laboratory Practices. The independent ethical board of CPN approved the animal use and study protocols (approval number 007/2018 signed on November 29, 2018).

Rats were randomized into 7 groups (10 rats/ group): a negative control (treated with vehicle, Tween $\left.65 / \mathrm{H}_{2} \mathrm{O}\right)$ and six groups which were administered kanamycin to induce AKI: a positive control group treated with Tween $65 / \mathrm{H}_{2} \mathrm{O}$, four groups treated with D-005 $(25,100,200$, and $400 \mathrm{mg} / \mathrm{kg}$ ) and one group treated with GSE $(200 \mathrm{mg} / \mathrm{kg})$. The dosage schedule of D-005 was based on its antioxidant and antiinflammatory previous effects ${ }^{15}$. The chosen dose of GSE has shown antioxidant effects in previous studies and it falls within the range of doses previously used in nephrotoxicity models ${ }^{18-20}$. D-005, the vehicle, and GSE were administered orally by intragastric gavage in order to guarantee that rats receive the exact dose and according to previous studies ${ }^{15,21}$. All treatments were administered once daily for seven days.

AKI was induced by daily injections with kanamycin (kanamycin sulfate, $500 \mathrm{mg} / \mathrm{kg}$, i.p.) during seven days concurrently with the course of D-005, vehicle, and GSE treatments, $1 \mathrm{~h}$ after receiving the treatments with D-005, vehicle, and GSE. Twentyfour hours after the last treatment (day $\left.8^{\text {th }}\right)$, rats were anesthetized using sodium thiopental $(30 \mathrm{mg} / \mathrm{kg})$ and blood samples were taken from the abdominal aorta for blood biochemistry (serum concentrations of uric acid and urea) and determination of oxidation parameters (concentrations of MDA and SH groups as well as CAT activity). Immediately, both kidneys were removed; the left one was used for histopathological analysis and the right one was used for the determination of the oxidation parameters. Kidneys used for biochemical analysis were homogenized using a blade homogenizer (Ultra-Turrax) in an ice bath and a suitable buffered solution according to the technique to be performed. The homogenized samples were stored at $-20{ }^{\circ} \mathrm{C}$.

\section{BLOOD BIOCHEMISTRY DETERMINATIONS}

Uric acid and urea concentrations were measured in serum samples using Spinreact Signature reagent kits in an UV-Genesys 10S Spectrophotometer. The uric acid readings were made at $520 \mathrm{~nm}$ and reported as $\mu \mathrm{mol} / \mathrm{L}$, whereas urea readings were made at $340 \mathrm{~nm}$ and reported as $\mathrm{mg} / \mathrm{dL}$.

\section{HISTOPATHOLOGICAL PROCESSING AND ANALYSIS}

Kidneys were sectioned through the hilum following the sagittal plane and immediately immersed in 4 $\%$ buffered formalin. Subsequently, samples were subjected to ethanol, xylol and paraffin passes. Then, they were embedded in paraffin blocks and $3 \mu \mathrm{m}$-thick sections were obtained using a Sakura microtome. 
Two histological slides per animal were prepared: one slide was stained with hematoxylin and eosin, and the second one with periodic Schiff's acid (PAS) ${ }^{22}$.

Histopathological analysis was performed from the upper to the lower pole of each kidney hemisection. Morphology of glomeruli and proximal tubules, as well as the condition of the interstitium, were studied by means of a Zeiss Primo Star light microscope. The following variables were assessed:

- Glomerular damage: evaluated using the following 0-2 scores: 0: normal appearance; 1 : mesangial expansion (wide, strongly stained areas in the mesangium) and/or mesangial hypercellularity (presence of more than three nuclei in the mesangium); 2: glomerular tuft retraction with increased Bowman's space.

- Tubular damage: assessed using the following 0-4 scores: 0: normal structure; 1: some tubules with damaged or necrotic cells; 2 : isolated areas of tubular necrosis; 3 : frequent areas of tubular necrosis; 4: widespread or diffuse necrosis.

- Interstitial damage: evaluate by the presence or absence of inflammatory cells in the interstitium using the following scores (0-2): 0 : absence of inflammatory cells; 1 : scarce inflammatory cells (1-5 cells per field); 2: abundant inflammatory cells (more than 5 cells/field).

- Global renal damage: calculated from the sum of the values of glomerular damage, tubular damage, and interstitial damage assigned to each animal.

\section{Determination of the MDA concentration}

The determination of thiobarbituric acid reactive substances (TBARS) was carried out according to a previous described technique ${ }^{23}$. Briefly, the reaction mixture (plasma or kidney homogenate) was treated with $0.2 \mathrm{~mL}$ sodium dodecyl sulfate (SDS) $(8.1 \%), 1.5$ $\mathrm{mL}$ of acetic acid $(20 \%, \mathrm{pH} 3.5)$, and $1.5 \mathrm{~mL}$ of an aqueous solution of thiobarbituric acid $(0.8 \%)$ and then heated at $95{ }^{\circ} \mathrm{C}$. In order to avoid the production of additional peroxidation that could constitute an error in the determination during the heating process, butylated hydroxytoluene $(1 \mathrm{mmol} / \mathrm{L})$ was added to the medium. Samples were cooled and $5 \mathrm{~mL}$ of an n-butanol-pyridine mixture $(15: 1 \mathrm{v} / \mathrm{v})$ was added to each one. They were then vigorously shaken using a vortex, centrifuged at 4,000 rpm for $20 \mathrm{~min}$. The organic layer was removed and its absorbance was read at $534 \mathrm{~nm}$ in a spectrophotometer. For calculations of TBARS levels, a standard curve with MDA bis(dimethyl acetal) was plotted. MDA values were reported as nmol $\mathrm{MDA} / \mathrm{mg}$ of protein. Protein concentrations were obtained by the modified Lowry method ${ }^{24}$.

\section{Determination OF SH GROUP CONCENTRATION}

In brief, $600 \mu \mathrm{L}$ tris-ethylenediamine tetraacetic acid buffer $(20 \mathrm{mmol} / \mathrm{L}), \mathrm{pH} 8.2,40 \mu \mathrm{L} \mathrm{5,5-dithiobis-(2-}$ nitrobenzoic acid) (DTNB) $(10 \mathrm{mmol} / \mathrm{L})$, and $3.16 \mathrm{~mL}$ ethanol $(100 \%)$ were added to an aliquot of $200 \mu \mathrm{L}$ of the sample (plasma or kidney homogenate). The mixture was incubated during $15-20 \mathrm{~min}$ at room temperature and subsequently centrifuged at 3,000 $\mathrm{rpm}$ for $10 \mathrm{~min}$. The supernatant absorbance was read at $412 \mathrm{~nm}$. A blank was prepared with DTNB, and total concentration of $\mathrm{SH}$ was calculated using 13,600 $\mathrm{cm}-1 \mathrm{M}-1$ absorptivity and reported in $\mathrm{mmol} / \mathrm{L}^{25}$.

\section{ASSESSMENTS OF CAT ACTIVITY}

Firstly, $\mathrm{H}_{2} \mathrm{O}_{2}$ removal was controlled at $240 \mathrm{~nm}$ for $5 \mathrm{~min}$ in a spectrophotometer. To $10 \mu \mathrm{L}$ of sample (plasma or kidney homogenate), $2.89 \mathrm{~mL}$ potassium phosphate buffer $(50 \mathrm{mmol} / \mathrm{L}, \mathrm{pH} 7.4)$ was added. The reaction started by adding $0.1 \mathrm{~mL} \mathrm{H}_{2} \mathrm{O}_{2}$ to a final volume of $3 \mathrm{~mL}$ at $25^{\circ} \mathrm{C}$. CAT activity was calculated by the molar extinction coefficient $\left(43.6 \times 10^{-3}\right)$ and was expressed in IU/min mg of protein $\times 10^{-126}$.

The inhibition percentages of D-005 and GSE groups for the variables uric acid, urea, global kidney damage, MDA, and $\mathrm{SH}$ groups were calculated using the following formula:

$$
\mathrm{I}=100-\frac{(\mathrm{T}-\mathrm{NC}) \times 100}{\mathrm{PC}-\mathrm{NC}}
$$

wherein: $\mathrm{I}$ is inhibition, $\mathrm{T}$ is treated group mean, NC is Negative control mean, and PC is Positive control mean.

For CAT activity, the restoration percentages of D-005 and GSE groups were calculated using the following formula:

$$
\mathrm{R}=100-\frac{(\mathrm{NC}-\mathrm{T}) \times 100}{\mathrm{NC}-\mathrm{PC}}
$$

wherein: $\mathrm{R}$ is restoration, $\mathrm{T}$ is treated group mean, $\mathrm{NC}$ is Negative control mean, PC: Positive control mean.

\section{STATISTICAL ANALYSIS}

Comparisons between groups was performed using the non-parametric Mann Whitney U test. Differences 
were considered statistically significant at a value of $\mathrm{p}<0.05$. Statistical analyses were performed using the Prism 5.0 software for Windows (Graphpad Software Inc., San Diego, CA, USA). Dose/effect relationship analyses were based on the linear regression and correlation method using Origin software version 5.0, Microcal Software, Inc. 1991-1997.

\section{Results}

\section{EFFECTS OF D-005 ON AKI BIOMARKERS}

Kanamycin caused a marked and significant increase on uric acid and urea serum levels in the positive control group compared to the negative control group. GSE, used as a reference substance, markedly and significantly decreased the concentrations of uric acid and urea, compared to the positive control, reaching 93.0 and $64.3 \%$ inhibition, respectively (Table 1 ).

D-005 significantly diminished in a dosedependent way the increase in uric acid $(\mathrm{p}=0.023, \mathrm{r}$ $=0.976)$ and urea $(\mathrm{p}=0.039, \mathrm{r}=0.960)$ serum levels, starting from the dose of $100 \mathrm{mg} / \mathrm{kg}$ and reaching the highest percentages of inhibition at $400 \mathrm{mg} / \mathrm{kg}(96.6$ $\%$ in uric acid and $70.3 \%$ in urea) (Table 1 ).

\section{EFFEcts of D-005 on RENAL HISTOPATHOLOgY}

The normal structure of the kidney parenchyma was observed in the rats of the negative control group, showing prominent PAS-positive brush borders in proximal tubules (Figure 1A). Rats belonging to the positive control group presented an increased glomerular mesangium, mesangial hypercellularity, and on occasions, retraction of glomerular tuft with enlarged Bowman's space, loss of brush borders and frequent tubular necrosis, as well as peritubular inflammatory infiltrate in the middle zone of kidney cortex (Figure 1B).

Additionally, the positive control group displayed marked and significant increase in histopathological scores of glomerular, tubular, and interstitial damage, as well as global kidney damage, which was obtained by the contribution of these three variables (Tables 2 and 3).

GSE, the reference substance in this study, partially prevented kanamycin-induced histopathological changes in kidney structures, showing numerous proximal tubules with well-preserved brush borders (Figure 1C). GSE was also found to significantly prevent increased glomerular, tubular, and interstitial damage scores, as well as kanamycin-induced global kidney damage (Tables 2 and 3).

Treatments with D-005, from the lowest dose evaluated, protected kidney parenchyma structures (glomeruli, proximal tubules, and interstitium) from the injury induced by kanamycin (Figure 1D, E) and caused a significant decrease of the histopathological variables: glomerular, tubular, and interstitial damage, as well as global kidney damage. The effects of D-005 over interstitial and global kidney damages were dose-dependent $(\mathrm{p}=0.020, \mathrm{r}=0.980$ and $\mathrm{p}=0.057$, $\mathrm{r}=0.942$, respectively). The highest percentages of inhibition were obtained with the dose of $400 \mathrm{mg} / \mathrm{kg}$ of D-005 in both variables (Tables 2 and 3 ).

\section{EFFECTS OF D-005 ON OXIDATIVE STRESS MARKERS}

Rats in the positive control group, treated with kanamycin, achieved significantly higher values of MDA and SH groups, as well as a depletion of CAT activity compared to the negative control, both in plasma and kidney homogenate (Tables 4 and 5).

The reference substance (GSE) significantly decreased MDA and $\mathrm{SH}$ group concentrations and partially restored CAT activity in plasma and kidney homogenate (Tables 4 and 5).

D-005 at all the tested doses $(25,100,200$, and 400 $\mathrm{mg} / \mathrm{kg}$ ) significantly diminished the increase in MDA concentration in both plasma and kidney homogenate,

TABLE 1 EFFECTS OF D-005 ON SERUM CREATININE AND URIC ACID CONCENTRATIONS IN RATS WITH KANAMYCIN-INDUCED
ACUTE KIDNEY INJURY

GSE: grape seed extract, I: inhibition. Data are reported as mean \pm SEM (standard error of the mean). ${ }^{*} p<0.05 ;{ }^{* *} p<0.01 ;{ }^{* * *} p<0.001 ;$ Comparison with the positive control group. Mann Whitney-U test. 


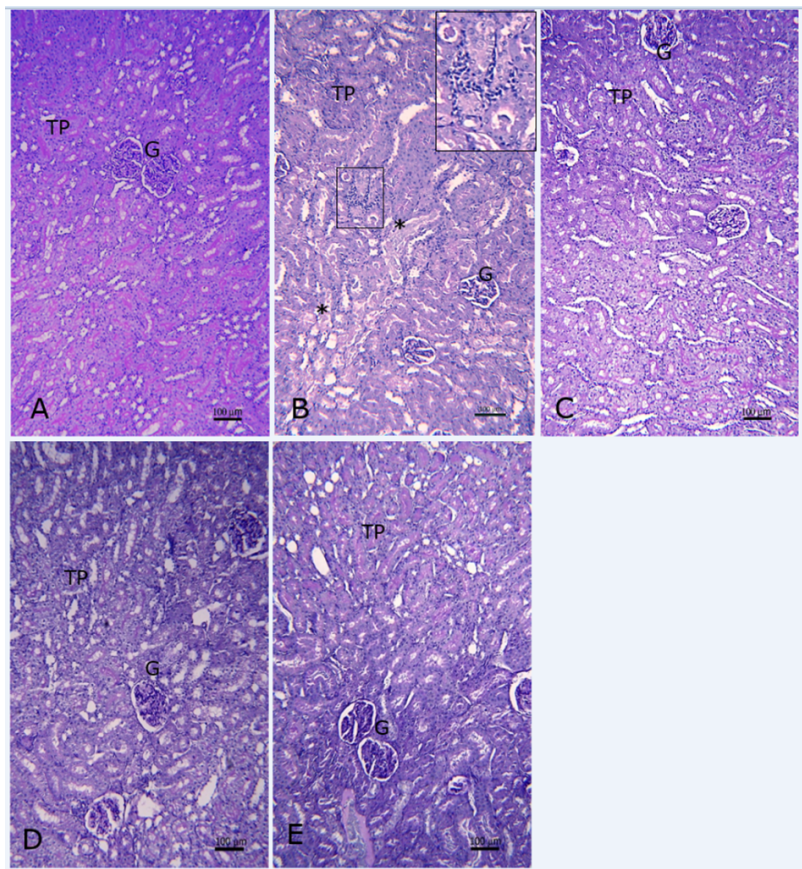

Figure 1. Renal cortex of rats with PAS staining. A representative image of each experimental group is shown. A) Negative control, B) Positive control (Kanamycin), C) Grape seed extract $(200 \mathrm{mg} / \mathrm{kg})+$ Kanamycin, D) D-005 25 mg/kg + Kanamycin, E) D-005 400 mg/kg + Kanamycin. Bars- $100 \mu \mathrm{m}$. G: glomeruli; TP: proximal tubules; * tubular necrosis; rectangle in $\mathrm{B}$ encloses peritubular inflammatory infiltrate (insert at higher magnification in the upper right corner).

reaching highest percentages of inhibition at doses of $400 \mathrm{mg} / \mathrm{kg}$ in plasma and $200 \mathrm{mg} / \mathrm{kg}$ in tissue sample (76.5 and $100 \%$ respectively) (Tables 4 and 5).

In addition, D-005 significantly decreased $\mathrm{SH}$ groups in a dose-dependent manner both in plasma $(\mathrm{p}=0.012, \mathrm{r}=0.987)$ and kidney homogenate $(\mathrm{p}=$ $0.025, r=0.975)$, being the highest percentage of inhibition at the dose of $400 \mathrm{mg} / \mathrm{kg}$ (88.5\% in plasma and $99.01 \%$ in kidney homogenate) (Tables 4 and 5 ).

The effects of D-005 $(25-400 \mathrm{mg} / \mathrm{kg})$ on CAT activity in plasma and kidney homogenate are also shown in Tables 4 and 5. D-005, from the lowest dose tested, restored CAT activity in a significant and dosedependent manner $(\mathrm{p}=0.039, \mathrm{r}=0.960$ in plasma and $\mathrm{p}=0.019, \mathrm{r}=0.981$ in kidney homogenate), reaching the highest recovery percentage at the dose of $400 \mathrm{mg} / \mathrm{kg}(97.02 \%$ in plasma and $69.6 \%$ in kidney homogenate).

\section{Discussion}

The results of this study demonstrate the protective effect of repeated oral doses of D-005 on kanamycininduced AKI.

The biochemical and histopathological changes in the positive control group (kanamycin-treated rats) is in accordance to those described by other authors under similar conditions ${ }^{27,28}$. The increase in serum concentrations of uric acid and urea in this group indicates a decrease in the glomerular filtration rate, which constitutes a hallmark of $\mathrm{AKI}^{29-31}$, being the increase of urea in the Positive control group in agreement with values reported in diverse animal models of aminoglycoside-induced $\mathrm{AKI}^{8}$.

Moreover, although the serum creatinineconcentration quantification constitutes the gold standard in the clinical diagnosis of AKI, in the model of aminoglycoside-induced nephrotoxicity diagnosis is better established by the increase in urea concentration -sometimes expressed as BUN - since urea increases 60 times more than creatinine in this type of experimental damage ${ }^{8,10}$. Therefore, not having quantified the creatinine concentration cannot be considered a limitation of this study.

Regarding our histopathological findings, the nephrotoxic treatment impaired the morphology of renal cortex parenchyma, which showed glomerular alterations, tubular necrosis, and inflammatory infiltrate close to necrotic tubules. These results resemble those of previous outcomes based on gentamicin nephrotoxicity models, where the death of tubular cells has been recognized as the primary event due to the entry of AMG therein, whereas the infiltration of inflammatory cells and glomerular changes are considered secondary events promoted by tubular dysfunction 32,33 .

As expected, GSE, used as a reference substance, markedly and significantly prevented the rise of uric acid and urea serum concentrations induced by kanamycin. Likewise, GSE significantly decreased the histopathological damage of kidney structures, compared to the positive control group, in agreement with previous reports ${ }^{34}$.

Taking into account the increase in biochemical parameters and histopathological alterations of kidney structures found in the positive control group, which are both typical of AKI, and that GSE, used as a reference substance, prevented the changes induced by kanamycin, the rat model used and the results obtained in our experimental conditions are validated.

In the present work, it was shown that D-005 partially restored glomerular filtration rate, since it decreased serum concentrations of uric acid and urea. The minimum effective dose of D-005 in both parameters was $100 \mathrm{mg} / \mathrm{kg}$. The protection of renal function was accompanied by the preservation of renal parenchyma 


\begin{tabular}{|c|c|c|c|c|c|c|c|}
\hline Table 2 & $\begin{array}{l}\text { EFFECTS OF D-005 ON } \\
\text { RATS WITH KANAMYCIN-II }\end{array}$ & $\begin{array}{l}\text { RENAL HISTOPATHOLOGICA } \\
\text { NDUCED ACUTE KIDNEY IN }\end{array}$ & $\begin{array}{l}\text { SCO } \\
\text { URY }\end{array}$ & OF GLOMERULAR, & $U$ & ID IIVIERSIIIIAL DAI & $S$ IN \\
\hline Treatmen & & $\begin{array}{c}\text { Glomerular damage } \\
\text { (score) }\end{array}$ & $\begin{array}{c} \\
\text { I } \\
(\%)\end{array}$ & $\begin{array}{c}\text { tubular damage } \\
\text { (score) }\end{array}$ & $\begin{array}{c}\text { I } \\
(\%) \\
\end{array}$ & $\begin{array}{c}\text { Interstitialdamage } \\
\text { (score) }\end{array}$ & $\begin{array}{c}\text { I } \\
(\%)\end{array}$ \\
\hline Negative o & trol (vehicle) & $0.80 \pm 0.13^{* * *}$ & - & $0.10 \pm 0.10^{* * *}$ & - & & - \\
\hline Positive co & ol (vehicle + kanamycin) & $1.90 \pm 0.10$ & - & $2.84 \pm 0.23$ & - & $1.90 \pm 0.10$ & - \\
\hline D-005 (25 & $\mathrm{g} / \mathrm{kg})+$ kanamycin & $1.24 \pm 0.25^{*}$ & 59.6 & $1.80 \pm 0.29 *$ & 37.9 & $1.40 \pm 0.16^{*}$ & 26.3 \\
\hline D-005 (10 & $\mathrm{gg} / \mathrm{kg})+$ kanamycin & $1.22 \pm 0.25^{*}$ & 61.4 & $1.78 \pm 0.33^{*}$ & 38.7 & $1.20 \pm 0.29^{*}$ & 36.8 \\
\hline D-005 (20 & $\mathrm{g} / \mathrm{kg})+$ kanamycin & $1.12 \pm 0.18^{* *}$ & 70.6 & $1.71 \pm 0.25^{* *}$ & 41.2 & $1.13 \pm 0.18^{* *}$ & 40.5 \\
\hline D-005 (40) & $\mathrm{g} / \mathrm{kg})+$ kanamycin & $1.10 \pm 0.10^{* * *}$ & 72.5 & $1.64 \pm 0.12^{* * *}$ & 43.8 & $1.10 \pm 0.10^{* * *}$ & 42.1 \\
\hline GSE $(200$ & g/kg) + kanamycin & $1.10 \pm 0.23^{* *}$ & 72.5 & $1.60 \pm 0.34^{*}$ & 43.9 & $1.40 \pm 0.16^{*}$ & 26.3 \\
\hline
\end{tabular}

GSE: grape seed extract; I: inhibition. Data are reported as mean \pm SEM (standard error of the mean). ${ }^{*} p<0.05 ;{ }^{*} p<0.01$; ${ }^{*}{ }^{*} p<0.001 ;$ Comparison with the positive control group. Mann Whitney U test.

\begin{tabular}{lcc} 
TABLE $3 \quad$ EFFECTS OF D-005 ON GLOBAL RENAL DAMAGE IN RATS WITH KANAMYCIN-INDUCED ACUTE KIDNEY INJURY \\
\hline Treatment & Global renal damage (score) & I (\%) \\
\hline Negative control (vehicle) & $0.90 \pm 0.10^{* * *}$ & - \\
Positive control (vehicle + kanamycin) & $6.54 \pm 0.36$ & 29.4 \\
D-005 $(25 \mathrm{mg} / \mathrm{kg})+$ kanamycin & $4.88 \pm 0.38^{*}$ & 44.9 \\
D-005 $(100 \mathrm{mg} / \mathrm{kg})+$ kanamycin & $4.01 \pm 0.63^{*}$ & 45.7 \\
D-005 $(200 \mathrm{mg} / \mathrm{kg})+$ kanamycin & $3.96 \pm 0.35^{* *}$ & 48.2 \\
D-005 $(400 \mathrm{mg} / \mathrm{kg})+$ kanamycin & $3.92 \pm 0.14^{* * *}$ & 41.5 \\
GSE $(200 \mathrm{mg} / \mathrm{kg})+$ kanamycin & $4.2 \pm 0.35^{* *}$ & 4 \\
\hline
\end{tabular}

GSE: grape seed extract; I: inhibition. Data are reported as mean \pm SEM (standard error of the mean). ${ }^{*} p<0.05 ;{ }^{*} p<0.01 ;{ }^{* *} p<0.001 ;$ Comparison with the positive control group. Mann Whitney U test.

\begin{tabular}{|c|c|c|c|c|c|c|c|}
\hline TABLE 4 & $\begin{array}{l}\text { EFFECTS OF D-005 } \\
\text { KANAMYCIN-INDUCE }\end{array}$ & $\begin{array}{l}\text { LASMA MDA } \\
\text { JTE KIDNEY INJU }\end{array}$ & SH & CONCENTRAT & & ACTIVITY IN RAT & \\
\hline Treatme & & $\begin{array}{c}\text { MDA } \\
\text { (nmol/mg of pt) }\end{array}$ & $\begin{array}{c}\text { I } \\
(\%) \\
\end{array}$ & $\begin{array}{c}\text { Grupos SH } \\
(\mathrm{mmol} / \mathrm{L})\end{array}$ & $\begin{array}{c}\text { I } \\
(\%) \\
\end{array}$ & $\begin{array}{c}\text { CAT } \\
(\mathrm{UI} / \mathrm{min} / \mathrm{mg} \text { of } \mathrm{pt})\end{array}$ & $\begin{array}{c}\mathbf{R} \\
(\%)\end{array}$ \\
\hline $\begin{array}{l}\text { Negative } \\
\text { Positive }\end{array}$ & $\begin{array}{l}\text { ntrol (vehicle) } \\
\text { trol }\end{array}$ & $1.41 \pm 0.13 * * *$ & - & $0.49 \pm 0.02 * * *$ & - & $4.14 \pm 0.40 * * *$ & - \\
\hline (vehicle & anamycin) & $4.50 \pm 0.24$ & - & $0.80 \pm 0.06$ & - & $1.02 \pm 0.19$ & - \\
\hline D-005 (2 & g/kg) + kanamycin & $2.99 \pm 0.18^{* * *}$ & 48.7 & $0.63 \pm 0.04^{*}$ & 53.4 & $3.27 \pm 0.24^{* * *}$ & 72.2 \\
\hline D-005 (1 & $n g / k g)+$ kanamycin & $2.85 \pm 0.22^{* * *}$ & 53.5 & $0.56 \pm 0.03^{* *}$ & 75.9 & $3.52 \pm 0.35^{* * *}$ & 80.2 \\
\hline D-005 (2 & $\mathrm{mg} / \mathrm{kg})+$ kanamycin & $2.38 \pm 0.31^{* * *}$ & 68.5 & $0.54 \pm 0.04^{* *}$ & 82.3 & $3.97 \pm 0.18^{* * *}$ & 94.7 \\
\hline D-005 (4 & $\mathrm{mg} / \mathrm{kg})+$ kanamycin & $2.14 \pm 0.29^{* * *}$ & 76.5 & $0.52 \pm 0.03^{* *}$ & 88.5 & $4.04 \pm 0.26^{* * *}$ & 97.0 \\
\hline GSE $(20)$ & g/kg) + kanamycin & $2.22 \pm 0.28^{* * *}$ & 73.7 & $0.60 \pm 0.02^{* *}$ & 64.8 & $3.53 \pm 0.26^{* * *}$ & 80.7 \\
\hline
\end{tabular}

GSE: grape seed extract; I: inhibition; R: restoration; pt: protein. Data are reported as mean \pm SEM (standard error of the mean). " $p<0.05 ;{ }^{* *} p<0.01$; ${ }^{* * *} p<0.001$; Comparison with the positive control group. Mann Whitney U test.

\begin{tabular}{|c|c|c|c|c|c|c|c|}
\hline TABLE 5 & \multicolumn{7}{|c|}{$\begin{array}{l}\text { EFFECTS OF D-005 ON MDA AND SH GROUPS CONCENTRATIONS AND CAT ACTIVITY IN KIDNEY HOMOGENATE } \\
\text { IN RATS WITH KANAMYCIN-INDUCED ACUTE KIDNEY INJURY INJURY }\end{array}$} \\
\hline \multicolumn{2}{|c|}{ Treatment } & $\begin{array}{c}\text { MDA } \\
(\mathrm{nmol} / \mathrm{mg} \text { de pt) }\end{array}$ & $\begin{array}{c}\text { I } \\
(\%)\end{array}$ & Grupos SH (mmol/L) & $\begin{array}{c}\text { I } \\
(\%)\end{array}$ & $\begin{array}{c}\text { CAT } \\
(\mathrm{UI} / \mathrm{min} / \mathrm{mg} \text { de } \mathrm{pt})\end{array}$ & $\begin{array}{c}\mathbf{R} \\
(\%)\end{array}$ \\
\hline \multicolumn{2}{|c|}{ Negative control (vehicle) } & $1.98 \pm 0.40^{* * *}$ & - & $0.67 \pm 0.02^{* * *}$ & - & $2.13 \pm 0.20^{* * *}$ & - \\
\hline \multicolumn{2}{|c|}{ Positive control } & $5.69 \pm 0.21$ & - & $1.14 \pm 0.06$ & - & $0.55 \pm 0.06$ & - \\
\hline \multicolumn{2}{|c|}{ D-005 (25 mg/kg) + kanamycin } & $2.58 \pm 0.4^{* * *}$ & 83.7 & $0.89 \pm 0.04^{* *}$ & 52.8 & $1.03 \pm 0.10^{* *}$ & 30.5 \\
\hline \multicolumn{2}{|c|}{ D-005 $(100 \mathrm{mg} / \mathrm{kg})+$ kanamycin } & $2.02 \pm 0.23^{* * *}$ & 98.8 & $0.74 \pm 0.04 * * *$ & 85.5 & $1.42 \pm 0.22^{* *}$ & 55.4 \\
\hline \multicolumn{2}{|c|}{ D-005 (200 mg $/ \mathrm{kg})+$ kanamycin } & $1.93 \pm 0.21^{* * *}$ & 100 & $0.71 \pm 0.06^{* * *}$ & 90.9 & $1.60 \pm 0.24^{* * *}$ & 66.4 \\
\hline \multicolumn{2}{|c|}{ D-005 $(400 \mathrm{mg} / \mathrm{kg})+$ kanamycin } & $1.93 \pm 0.30^{* * *}$ & 100 & $0.67 \pm 0.05^{* * *}$ & 99.0 & $1.65 \pm 0.45^{* * *}$ & 69.6 \\
\hline \multicolumn{2}{|c|}{ GSE $(200$ mg/kg) + kanamycin } & $2.42 \pm 0.51^{* * *}$ & 88.1 & $0.72 \pm 0.04^{* * *}$ & 90.1 & $1.40 \pm 0.30^{* *}$ & 53.4 \\
\hline
\end{tabular}

GSE: grape seed extract; I: inhibition; R: restoration; pt: protein. Data are reported as mean \pm SEM (standard error of the mean). ${ }^{*} p<0.05 ;{ }^{* *} p<0.01$; *** $p<0.001$; Comparison with the positive control group. Mann Whitney U Test. 
structures observed in the histopathological study, although the morphological protection was evidenced from the minimum D-005 dose $(25 \mathrm{mg} / \mathrm{kg})$.

Nephrotoxic treatment with gentamicin has been shown to cause an increase in COX-2 in rats and mice, which can be reversed after administration of antiinflammatory agents such as hesperidin, alpha linolenic acid, and an extract of Hypericum perforatum ${ }^{35-37}$. Further studies will elucidate if the anti-inflammatory effect of D-005, histopathologically proven in this study by decreasing the infiltration of inflammatory cells in the renal parenchyma is associated, at least partially, to its dual inhibitory capacity on 5- LOX and COX-2 enzymes, similar to flavocoxid ${ }^{16,38}$.

The renal accumulation of AMGs, like kanamycin, causes direct toxic effects on tubular cells, accompanied by microvascular inflammation and ischemia, which promote ROS generation. Furthermore, the biotransformation of these drugs in the kidney is carried out by kidney enzymes such as cytochrome P-450, which also induces the generation of ROS. Accordingly, AMGs induce lipid peroxidation and renal dysfunction mediated by increased ROS, as well as iron release from the mitochondria of cortical tubular cells ${ }^{39}$. This explains the results obtained in the present study in terms of increased concentrations of MDA and $\mathrm{SH}$ groups, as well as depleted CAT activity in both plasma and kidney homogenate in the positive control group.

GSE protected from kanamycin-induced oxidative damage by decreasing $\mathrm{MDA}$ and $\mathrm{SH}$ group concentrations and partially restoring CAT activity, both in plasma and kidney homogenate. The nephroprotective effects of GSE have been proven before in models of nephrotoxicity induced by other AMGs, such as amikacin and gentamicin, in relation to its anti-apoptotic and antioxidant properties ${ }^{34,40}$. The usefulness of GSE as a reference substance is proved herein using the model of kanamycin-induced AKI.

Antioxidants are the most studied protective agents in animal models of nephrotoxicity and have been shown to be the most valuable preventive strategy against AMG-induced AKI. In this sense, the best protection results have been obtained with antioxidant extracts from plants, being administered concomitantly with the AMG, either simultaneously or as a pre-treatment on the same day ${ }^{10}$. Examples of this are the antioxidant extracts from two species of Arecaceae (Cocos nucifera and Phoenix dactylifera) exhibiting protective effects against AKI, which were administered concomitantly with gentamicin ${ }^{11,12}$.
Therefore, the protective effects of D-005 on AKI verified in this study could also be attributed, at least partially, to its antioxidant properties, which is supported by the decrease of lipid peroxidation and protein oxidation, showed with reduction of MDA and $\mathrm{SH}$ groups respectively, and the enhancement of endogenous antioxidants, by restoring CAT activity.

The antioxidant and anti-inflammatory effects of D-005 could be attributed to its content of fatty acids as lauric acid, oleic acid, and myristic acid, which have shown these effects previously ${ }^{41,42}$. In addition, myristic acid has revealed a nephroprotective effect by reducing tubular necrosis in an experimental model of $\mathrm{AKI}^{43}$. Finally, the fact that extracts obtained from Cocos nucifera and Phoenix dactylifera, palms with fatty acid compositions similar to D-005, have demonstrated protection against gentamicin-induced nephrotoxicity supports our hypothesis ${ }^{11,12}$.

In this context, this study constitutes the first evidence of the nephroprotective efficacy of this mixture of fatty acids obtained from Cuban Acrocomia crispa on aminoglycosides-induced renal damage. Moreover, it was in accordance with previous results in preventing ischemia-reperfusioninduced renal damage ${ }^{15}$, and further studies will clarify the mechanisms by which D-005 exerts its nephroprotective effect in both models of AKI.

Overall, we can suggest that D-005 is a new substance with considerable potential benefit on AKI, either as an antioxidant supplement or as a treatment for this pathology.

In conclusion, the administration of repeated oral doses of D-005, concomitant with kanamycin, significantly protected rats from AKI, which could be related to the antioxidant and anti-inflammatory actions of this plant extract.

\section{Authors' Contribution}

All authors read and approved the paper. Sandra Rodríguez-Salgueiro: design of the research protocol, collection and analysis of data, preparation of manuscript. Leyanis Ocaña-Nápoles: collection, analysis and interpretation of data. Ambar OyarzábalYera: protocol review, collection and analysis of data, critical review of manuscript. Lucía GonzálezNúñez: interpretation of data, critical review of the manuscript. Giselle Breña Betancourt and María Flavia Pérez Pino: experimental procedures, collection of data. José Alberto Medina-Pírez: experimental procedures and processing of histological samples. 
S. Jiménez-Despaigne: experimental procedures, processing of samples and collection of data. V. Molina-Cuevas: protocol approval, manuscript critical review and final approval of the final version.

\section{CONFLict of INTEREST}

The authors declare that they have no conflict of interest related to the publication of this manuscript.

\section{References}

1. Nie S, Tang L, Zhang W, Feng Z, Chen X. Are there modifiable risk factors to improve AKI?. BioMed Res Int. 2017;2017:5605634.

2. Santos RPD, Carvalho ARDS, Peres LAB, Delfino VDA, Grion CMC. Non-recovery of renal function is a strong independent risk factor associated with mortality in AKI patients. Braz J Nephrol. 2020;42(3):290-9.

3. Khalili H, Bairami S, Kargar M. Antibiotics induced acute kidney injury: incidence, risk factors, onset time and outcome. Acta Med Iran. 2013;51(12):871-8.

4. Lopez-Novoa JM, Quiros Y, Vicente L, Morales AI, Lopez-Hernandez FJ. New insights into the mechanism of aminoglycoside nephrotoxicity: an integrative point of view. Kidney Int. 2011 Jan;79(1):33-45.

5. Karasawa T, Steyger PS. Intracellular mechanisms of aminoglycoside-induced cytotoxicity. Integrat Biol (Camb). 2011 Sep;3(9):879-86.

6. Alexandridis G, Liberopoulos E, Elisaf M. Aminoglycosideinduced reversible tubular dysfunction. Pharmacology. 2013 Mar;67(3):118-20.

7. Venkatachalam MA, Weinberg JM, Kriz W, Bidani AK. Failed tubule recovery, AKI-CKD transition, and kidney disease progression. J Am Soc Nephrol. 2015 Aug;26(8):1765-76.

8. Vicente-Vicente L, Casanova AG, Hernández-Sánchez MT, Pescador M, López-Hernández FJ, Morales AI. A systematic meta-analysis on the efficacy of pre-clinically tested nephroprotectants at preventing aminoglycoside nephrotoxicity. Toxicology. 2017 Feb;377:14-24.

9. Mahi-Birjand M, Yaghoubi S, Abdollahpour-Alitappeh M, Keshtkaran Z, Bagheri N, Pirouzi A, et al. Protective effects of pharmacological agents against aminoglycoside-induced nephrotoxicity: a systematic review. Expert Opin Drug Saf. $2020 \mathrm{Feb} ; 19(2): 167-86$.

10. Casanova AG, Vicente-Vicente L, Hernández-Sánchez MT, Pescador M, Prieto M, Martínez-Salgado C, et al. Key role of oxidative stress in animal models of aminoglycoside nephrotoxicity revealed by a systematic analysis of the antioxidant-tonephroprotective correlation. Toxicology. 2017 Jun;385:10-7.

11. Jose SP, Asha S, Krishnakumar IM, Ratheesh M, Savitha S, Sandya $S$, et al. Nephro-protective effect of a novel formulation of unopened coconut inflorescence sap powder on gentamicin induced renal damage by modulating oxidative stress and inflammatory markers. Biomed Pharmacother. 2017 Jan;85:128-35.

12. Celik OY, Irak K. Protective effect of date extract on rat nephrotoxicity induced by gentamicin, clinical, histological and antioxidant evidences. Cell Mol Biol (Noisy-le-Grand). 2018 Nov;64(14):108-13.

13. González VL, Sierra R, Mas R, Pérez Y, Oyarzábal A, Rodríguez $\mathrm{E}$, et al; inventor. Centro Nacional de Investigaciones Cientificas (CNIC); assignee. Compounds from the fruits of Acrocomia crispa and Acrocomia aculeata for use against oxidative stress and inflammation. Patent CU WO2013/189467 A2. 2015 Mar 16.

14. Sierra-Pérez RC, González-Canavaciolo VL, Rodríguez-Leyes EA, Marrero-Delange D, Vicente-Murillo R, Morales-Rico CL. Estudio fitoquímico de los frutos de Acrocomia crispa, palma endémica cubana. Rev CENIC Cienc Quím. 2014;45:41-7.
15. Oyarzábal-Yera A, Rodríguez-Salgueiro S, Merino-García N, Ocaña-Nápoles L, González-Núñez L, Mena-Valdés L, et al. Protective effects of D-005, a lipid extract from Acrocomia crispa fruits, against ischemia/reperfusion-induced acute kidney injury in rats. Kidney Res Clin Pract. 2019;38(4):462-71.

16. Pérez Y, Oyarzábal A, Sierra R, Mas R, Molina V, Jiménez S, et al. Inhibition of cyclooxygenase (COX) and 5-lipoxygenase (5-LOX) by D-005 (a lipid extract of Acrocomia crispa fruits). Bol Latinoam Caribe Plant Med Aromat. 2017;16(3):319-28.

17. Mena L, Sierra R, Valle M, Molina V, Rodriguez S, Merino $\mathrm{N}$, et al. Acrocomia crispa fruits lipid extract prevents LPSinduced acute lung injury in mice. Bol Latinoam Caribe Plant Med Aromat. 2019;18(1):16-26.

18. Yera AO, Cuevas VM, Ferreiro RM, Despaigne SJ, Sánchez DC. Effects of D-002, a grape seed extract and their combined therapy on oxidative markers in rats. REDVET - Rev Electrônica Vet. 2012;13:1-13.

19. Abdel-Hafez SMN, Rifaai RA, Elzaher WYA. Mechanism of grape seeds extract protection against paracetamol renal cortical damage in male Albino rats. Bratisl Med J. 2017;118(4):233-42.

20. Gao Z, Liu G, Hu Z, Li X, Yang X, Jiang BEI, et al. Grape seed proanthocyanidin extract protects from cisplatin-induced nephrotoxicity by inhibiting endoplasmic reticulum stressinduced apoptosis. Molecular Med Rep. 2014;9(3):801-7.

21. Salem NA, Salem EA. Renoprotective effect of grape seed extract against oxidative stress induced by gentamicin and hypercholesterolemia in rats. Renal Fail. 2011;33(8):824-32.

22. Salama AD, Cook HT. The renal biopsy. In: Taal MW, Chertow GM, Marsden PA, Sckorecki K, Yu A SL, eds. Brenner and rector's the kidney. 9th ed. Philadelphia: Saunders; 2011. p. 2962.

23. Ohkawa O, Ohishi I, Yagi K. Assay of lipid peroxides in animal tissues by the thiobarbituric acid reaction. Anal Biochem. 1979 Jun;95(2):351-8.

24. Markwell MAK, Haas SM, Bieber LL, Tolbert N. A modification of the Lowry procedure to simplify protein determination in membrane and lipoprotein samples. Analytic Biochem. 1978 Jun;87(1):206-10.

25. Hu ML. Measurement of protein thiol groups and glutatione in plasma. Methods Enzymol. 1994;233:380-2.

26. Aebi H. Catalase. In: Bergmeyer HU, ed. Methods of enzymatic analysis. New York: Academic Press; 1974. p. 673-80.

27. Kilany OE, Abdou RH, El-Beltagy MA, Mohammad HM. Protective effects of Tribulus terrestris against gentamicin mediated nephrotoxicity, oxidative damage and apoptosis in male rats. Egyptian Academic J Biol Sci B. Zool. 2020;12(1):41-58.

28. González-Núñez L, Rodríguez-Salgueiro S, Ocaña-Nápoles L, Oyarzábal-Yera A, Medina-Pírez JA, Pentón-Rodríguez O, et al. Histopathological changes in two models of acute kidney injury. Microsc Microanal. 2020 Apr;26(Suppl 1):S73-S4.

29. Kaushik M, Choo JCJ. Serum uric acid and AKI: is it time?. Clin Kidney J. 2016 Feb;9(1):48-50.

30. Chawla LS, Bellomo R, Bihorac A, Goldstein SL, Siew ED, Bagshaw SM, et al. Acute kidney disease and renal recovery: consensus report of the Acute disease quality initiative (ADQI) 16 Workgroup. Nature Rev Nephrol. 2017 Feb;13:241-57.

31. Bao YW, Yuan Y, Chen JH, Lin WQ. Kidney disease models: tools to identify mechanisms and potential therapeutic targets. Zool Res. 2018 Mar;39(2):72-86.

32. Randjelovic P, Veljkovic S, Stojiljkovic N, Sokolovic D, Ilic I. Gentamicin nephrotoxicity in animals: current knowledge and future perspectives. EXCLI J. 2017;16:388-99.

33. Yang X, Zhong H, Xu C, Xu G. Spotlights on antibioticinduced acute kidney injury: the evidence to date. Iran J Kidney Dis. 2019 Jan;13(1):10-20.

34. El-Ashmawy IM, El-Nahas AF, Salama OM. Grape seed extract prevents gentamicin-induced nephrotoxicity and genotoxicity in bone marrow cells of mice. Basic Clin Pharmacol Toxicol. 2006;99(3):230-6.

35. Subramanian P, Anandan R, Jayapalan JJ, Hashim $\mathrm{OH}$. Hesperidin protects gentamicin-induced nephrotoxicity via Nrf2/HO-1 signaling and inhibits inflammation mediated by NF- $\mathrm{KB}$ in rats. J Funct Foods. 2015;13:89-99. 
36. Kaplan HM, Izol V, Aridogan IA, Olgan E, Yegani AA, Pazarc1 P, et al. Protective effect of alpha-linolenic acid on gentamicin induced nephrotoxicity in mice. Int J Pharmacol. 2016;12(5):562-66

37. Kaplan HM, Izol V, Aridogan IA, Olgan E, Yegani AA, Pazarci $\mathrm{P}$, et al. Protective effect of Hypericum perforatum extract on gentamicin induced nephrotoxicity in mice. Int J Pharmacol. 2016;12:663-8.

38. El-Kashef DH, El-Kenawi AE, Suddek GM, Salem HA. Flavocoxid attenuates gentamicin-induced nephrotoxicity in rats. Naunyn Schmiedebergs Arch Pharmacol. 2015 Dec;388(12):1305-15.

39. Dennis JM, Witting PK. Protective role for antioxidants in acute kidney disease. Nutrients. 2017 Jul;9(7):718.
40. Ulusoy S, Ozkan G, Ersoz S, Orem A, Alkanat M, Yucesan FB, et al. The effect of grape seed proanthocyanidin extract in preventing amikacin-induced nephropathy. Renal Fail. 2012 Jan;34(2):227-34.

41. Marineli RS, Marques AC, Furlan CPB, Maróstica MR. Antioxidant effects of the combination of conjugated linoleic acid and phytosterol supplementation in Sprague-Dawley rats. Food Res Int. 2012;49(1):487-93.

42. Morais SM, Nascimento JET, Silva AAS, Junior JERH, Pinheiro DCSN, Oliveira RV. Fatty acid profile and anti-inflammatory activity of fixed plant oils. Acta Sci Vet. 2017;45:1-8.

43. Monserrat AJ, Cutrin JC, Coll C. Protective effect of myristic acid on renal necrosis occurring in rats fed a methyl-deficient diet. Res Exp Med (Berl). 2000 Feb;199(4):195-206. 